\title{
PREVALENCE OF PRESENILE DEMENTIA IN A TERTIARY OUTPATIENT CLINIC
}

\author{
Satomi Fujihara', Sonia M.D. Brucki', Maria Sheila G. Rocha3, \\ Alzira A. Carvalho ${ }^{4}$ Ana C. Piccolo ${ }^{5}$
}

\begin{abstract}
There are very few reports about prevalence of presenile dementia in Brazil. We reviewed files of patients evaluated with early onset of cognitive impairment in our institution. Among 141 patients $(61 \%$ males) there was no difference between gender by age at onset or at first evaluation. We have observed an increasing number of patients after 50 years. The most frequent causes were: vascular dementia (36.9\%), Alzheimer's disease (20.3\%) and traumatic brain injury (9.2\%). There was difference among dementia type by age of onset and first evaluation, educational level and length of dementia. These results may be compared with those from other neurologic services in order to replicate or confirm these results.
\end{abstract}

KEY WORDS: presenile dementia, vascular dementia, Alzheimer's disease, epidemiology.

\section{Prevalência de demência pré-senil num ambulatório terciário}

RESUMO - Em nosso meio há raros estudos que verifiquem quais as causas mais prevalentes de demência pré-senil. Avaliamos retrospectivamente os prontuários de pacientes com início precoce de alterações cognitivas, ambulatório de Neurologia da Cognição do Hospital Santa Marcelina. Entre os 141 sujeitos (61\% de homens) não houve diferença quanto às idades de início e à primeira consulta e escolaridade entre os sexos. Observamos aumento no número de demência após os 50 anos. A causa mais freqüente foi vascu$\operatorname{lar}(36,9 \%)$, seguida por doença de Alzheimer (20,3\%) e secundária a trauma cranio encefálico $(9,2 \%)$. Houve diferença entre os tipos de demência quanto à idade na primeira consulta e idade de início, escolaridade e duração do quadro. Ao contrário de outros estudos o diagnóstico mais freqüente foi demência vascular. Novos estudos em nosso meio deverão ser realizados para avaliar este achado nas demências de início precoce.

PALAVRAS-CHAVE: demência pré-senil, demência vascular, doença de Alzheimer, epidemiologia.

Dementia is a disorder of greater prevalence in older subjects, but many cases can begin in an early age, affecting people in a productive phase of their lives. A syndrome characterized by many cognitive deficits of sufficient severity to interfere with daily life activities and in quality of life. It is a public health problem due its expensive treatment and dependence of patients for governmental sources for sustainability. There are a few studies in epidemiology of presenile dementia comparing to an older onset or familiar Alzheimer's disease (AD $)^{1-3}$.

The prevalence of presenile dementia is lower that ones with onset in the elderly. Harvey et al. ${ }^{4}$ reported that the prevalence increases exponentially between 45 to 60 years of age; this finding was replicated by another three epidemiological studies ${ }^{5-7}$. The most frequent diagnosis in early onset dementia is:
Alzheimer's disease, followed by vascular dementia (VaD) and frontotemporal dementia (FTD) ${ }^{8}$.

There are no studies analyzing the prevalence of presenile dementia in our country in a search in MEDLINE. Other authors have reported diagnostic prevalence in senile dementia or overall rates of dementia in their outpatient clinics ${ }^{9-12}$ or institutionalized patients ${ }^{13}$. One report was presented as abstract and has reviewed a considerable number of patients $(n=619)$ and found a prevalence of $28.6 \%$ of presenile dementia ${ }^{14}$. The aim of our study is to describe the prevalence of different etiologies of presenile dementia in a tertiary specialized outpatient clinic of Santa Marcelina Hospital, a reference for about three million inhabitants of East of São Paulo City. This population is characterized by lower socioeconomic and educational levels.

\footnotetext{
Hospital Santa Marcelina, São Paulo SP, Brasil: ${ }^{1}$ Residente do Serviço de Neurologia; ${ }^{2}$ Doutora em Medicina, Responsável pelo Ambulatório de Cognição, Preceptora da Residência em Neurologia; ${ }^{3}$ Doutora em Medicina, Chefe do Serviço; ${ }^{4}$ Doutora em Medicina, Preceptora da Residência; ${ }^{5}$ Mestre em Neurologia, Preceptora da Residência.
}

Received 16 December 2003, received in final form 4 March 2004. Accepted 5 April 2004.

Dra. Sonia M.D. Brucki - Rua Humberto Primo 740/123 - 04018-032 São Paulo SP - Brasil. E-mail: sbrucki@uol.com.br 
Table 1. Demographic and clinical variables of presenile patients $(N=141)$.

\begin{tabular}{lcccc}
\hline & Mean (SD) & Median value & minimum & maximum \\
\hline Age (years) & $53.3(12.1)$ & 57 & 21 & 65 \\
Educational level (years) & $3.6(3.1)$ & 4 & 0 & 12 \\
Age of onset & $51(11.4)$ & 54 & 21 & 65 \\
Length of dementia (months) & $42.2(44.5)$ & 24 & 2 & 306 \\
Initial MMSE & $18.2(6.0)$ & 18 & 2 & 29 \\
\hline
\end{tabular}

\section{METHOD}

We reviewed 311 files of patients consecutively seen in the Cognitive Clinic of Santa Marcelina Hospital, from 1997 to 2003, which have been sent for evaluation of cognitive complaints. This research was approved by the ethics committee. A hundred forty one subjects fulfilled the criteria for dementia (DSM-IV) ${ }^{15}$ and the clinical onset of dementia has begun before 65 years old of age (presenile dementia). All patients had clinical, neurological and cognitive examinations and a complete laboratory evaluation: blood count with erythrocyte sedimentation rate, serum cholesterol, triglycerides, creatinine, urea, sodium, potassium, calcium, phosphorus, protein, glucose, bilirubin, alkaline phosphatase, ALT and AST, thyroid hormones, VDRL and FTA-abs reactions. Besides that, cerebral spinal fluid when necessary, and viral serology (IHV, hepatitis C and B virus) was performed. The type of dementia was based on the following criteria: AD was made according to National Institute of Neurological and Communicative Disorders and Stroke/ Alzheimer's Disease and Related Disorders Association (NINCDS/ ADRDA) ${ }^{16}$; VaD followed National Institute of Neurological Disorders and Stroke - Association Internationale pour la Recherche et l'Enseignement en Neu-

Table 2. Frequency of dementia by age of onset and gender.

\begin{tabular}{lcc}
\hline $\begin{array}{l}\text { Age of onset } \\
\text { (years) }\end{array}$ & $\begin{array}{c}\text { Men } \\
(\mathrm{n}=86) \\
\mathrm{N}(\%)\end{array}$ & $\begin{array}{c}\text { Women } \\
(\mathrm{n}=55) \\
\mathrm{N}(\%)\end{array}$ \\
\hline$<30$ & $5(5.8)$ & $5(9.1)$ \\
$30-34$ & $2(2.3)$ & $3(5.4)$ \\
$35-39$ & $4(4,6)$ & $4(7,3)$ \\
$40-44$ & $6(7.0)$ & $4(7.3)$ \\
$45-49$ & $8(9.3)$ & $7(12.7)$ \\
$50-54$ & $10(11.6)$ & $9(16.4)$ \\
$55-59$ & $25(29.1)$ & $8(14.5)$ \\
$60-65$ & $19(22.1)$ & $14(25.4)$ \\
No date & $7(8.1)$ & $1(1.8)$ \\
\hline
\end{tabular}

rosciences (NINDS/ AIREN) ${ }^{17}$ criteria, Lewy body disease followed guidelines proposed by McKeith et al. ${ }^{18}$, revised in 199919; FTD diagnosis was based on Lund and Manchester criteria ${ }^{20}$ and alcoholic dementia by DSM-IV criteria ${ }^{15}$. For patients with memory complaints and objective memory impairment without dementia, we used the criteria for mild cognitive impairment $(\mathrm{MCl})^{21}$. We also observed risk factors that may corroborate with the clinical picture of dementia, particularly those related with cerebrovascular disease and family history for dementia. The severity was evaluated according to the initial scores on Mini-Mental State Examination (MMSE) ${ }^{22}$.

Statistical analysis was performed utilizing STATISTICA. T-test was used for demographic variables and analysis of variance with Tukey test.

\section{RESULTS}

A hundred forty one files of presenile dementia subjects were examined cautiously, other four patients were diagnosed as $\mathrm{MCl}$ (mean age of 53. SD $=10.4$ years and a mean time of outcome of 36 months). In Table 1 we describe clinical and demographic variables of early onset dementia patients.

Table 3. Etiology of presenile dementia $(n=141)$.

\begin{tabular}{lcc}
\hline Etiology & $\mathrm{N}$ & $\%$ \\
\hline Vascular dementia & 52 & 36.9 \\
Probable Alzheimer's disease & 18 & 12.8 \\
Possible Alzheimer's disease & 12 & 8.5 \\
Traumatic brain injury & 13 & 9.2 \\
Frontotemporal dementia & 7 & 5.0 \\
Alcoholic dementia & 7 & 5.0 \\
Normal pressure hydrocephalus & 6 & 4.2 \\
Depression & 6 & 4.2 \\
Anoxic encephalopathy & 4 & 2.8 \\
Miscellanea* & 16 & 11.3 \\
\hline * multiple sclerosis, metabolic causes, Hashimoto's encephalopathy, vasculi- \\
$\begin{array}{l}\text { tis, progressive supranuclear palsy, metachromatic leukodystrophy, Parkinson's } \\
\text { disease dementia, corticobasal degeneration, neurocysticercosis. }\end{array}$
\end{tabular}


Table 4. Prevalence of dementia types by age group.

\begin{tabular}{lcccccc}
\hline Age & Possible AD & Probable AD & VaD & TBI & FTD & Alcohol \\
\hline$<30$ & - & - & - & $7(53.8 \%)$ & - & - \\
$30-34$ & - & - & $3(5.8 \%)$ & - & $1(14.3 \%)$ & - \\
$35-39$ & - & $1(5.5 \%)$ & $2(3.8 \%)$ & $1(7.7 \%)$ & - & $1(14.3 \%)$ \\
$40-44$ & - & $1(5.5 \%)$ & $4(7.7 \%)$ & - & $1(14.3 \%)$ & $1(14.3 \%)$ \\
$45-49$ & $1(8.3 \%)$ & $5(27.8 \%)$ & $5(9.6 \%)$ & - & - & $2(28.6 \%)$ \\
$50-54$ & $1(8.3 \%)$ & $2(11.1 \%)$ & $11(21.1 \%)$ & $3(23.1 \%)$ & $2(28.6 \%)$ & - \\
$55-59$ & $3(25 \%)$ & $2(11,1 \%)$ & $13(25 \%)$ & $1(7.7 \%)$ & $2(28.6 \%)$ & $2(28.6 \%)$ \\
$60-65$ & $7(58.3 \%)$ & $7(38.9 \%)$ & $14(26.9 \%)$ & $1(7.7 \%)$ & $1(14.3 \%)$ & $1(14.3 \%)$ \\
total & $12(100 \%)$ & $18(100 \%)$ & $52(100 \%)$ & $13(100 \%)$ & $7(100 \%)$ & $7(100 \%)$ \\
\hline
\end{tabular}

There was a male predominance in the sample $(61 \%)$ with similar distribution between gender: in age $(p=0.3302)$ and educational level $(p=0.7469)$. Mean age of men was 54.2 years and median value of 58 years. Women had mean age of 52.1 years and median value of 54 years. The mean schooling was 3.72 and 3.53 years, for men and women, respectively. There was no difference at age of onset between gender, a mean of 49.1 years in males and 52.4 years in females. In Table 2 we show the frequency by five years interval. An increased prevalence after 45 years old was observed. After 50 years there was more than an half of the sample in both sexes ( $61.8 \%$ of men and $56.3 \%$ of women).

$\mathrm{VaD}$ dementia was the most frequent etiology (36.9\%) followed by AD (probable AD: $12.8 \%$ and possible $A D$ : $8,5 \%$ ). Traumatic brain injury (TBI) was the prime cause among nondegenerative dementias (9.2\%), see (Table) 3. In Table 4 we report frequencies by age groups by dementia.

Analysis of variance (ANOVA) was performed to compare dementia groups by demographic variables and initial scores on the MMSE. There were differences related to: age at onset in the first evaluation, $F(22,118)=3.8917, p<0.0001)$; age of onset by history, $F(21,111)=3.2482, p<0.0001$; years of schooling, $F(20,95)=2.6638, p=0.0007$; and length of dementia, $F(21,111)=1.7125, p=0.0388$. In the post-hoc analysis by Tukey's test, we observed differences between TBI and VaD patients by educational level ( $p=0.0471)$, with greater level for the first and more educated group. TBI subjects were different by age at the first evaluation when compared to $A D$ and $V a D$, these results were replicated in the analysis by age of onset, comparing with: $\operatorname{VaD}(p=0.0032)$, possible $A D(p=0.0002)$, and pro- bable AD ( $p=0.0013)$. In both situations age of TBI subjects was minor.

Familiar history was reported by 22 patients (15.6\% of sample): probable AD, 9 subjects $(40.9 \%)$; possible AD, 3 cases $(13.6 \%)$; FTD, 3 cases $(13.6 \%)$; and $\mathrm{VaD}, 3$ cases $(13.6 \%)$. These findings of familiar history correspond to $50 \%$ in probable $A D$, $25 \%$ of cases of possible AD, $42.8 \%$ of FTD, and only $5.8 \%$ of $\mathrm{VaD}$. The most frequent risk factors for cerebrovascular disease were: systemic hypertension $(41.8 \%)$, smoking $(25.5 \%)$, dyslipidemia $(24.1 \%)$, alcoholism (20.6\%), and diabetes (17\%). In $\mathrm{VaD}$ patients $78.8 \%$ reported previous stroke, and presented more risks for cerebrovascular disease, as expected: systemic hypertension ( $57.7 \%)$, dyslipidemia $(32.7 \%)$, smoking $(30.8 \%)$, diabetes $(21.1 \%)$, and alcoholism (17.3\%). Seizures were associated with dementia in 16 patients, five with $\mathrm{VaD}$ and one AD subject.

\section{DISCUSSION}

About half of evaluated patients $(46.6 \%)$ in our clinic met criteria for presenile dementia, in contrast to other preliminary study that an early onset of dementia has occurred in $28.6 \%{ }^{14}$; these findings confirm the obligation to pay attention for this diagnosis by clinicians and neurologists in general, in front of a young people with cognitive complaints. Our patients exhibited similar age on diagnosis time compared to another studies, Panegyres et al. ${ }^{23}$ observed a mean age of 54.2 years among their 150 patients and Harvey et al. ${ }^{24}$ in their prevalence study showed a little more old subjects (mean 58.7 years). Also there was a predominance of males in studies of early onset dementia ${ }^{23,24}$. 
$A D$ is the most frequent etiology in studies with early onset dementia 2,4,23-27, although in one report $\mathrm{VaD}$ is the most prevalent (Southampton area) ${ }^{26}$ as well as in the Japanese study ${ }^{28}$. In our clinic VaD was the most important cause of dementia, with a frequency of $36.9 \%$ and increasing prevalence after 50 years. These differences with other occidental studies may be dueto particular sample characteristics: lower socioeconomic level causing under risk factor control for cerebrovascular diseases, facilitated reference to our clinic, heterogeneous racial population (although with no Japanese descendents). The second more frequent type was $A D$, with increasing prevalence in older ages. Among young adults we had TBI and FTD as common etiologies, but the second was less frequent than other studies ${ }^{4,23}$. This fact does not seem to us a diagnostic failure, and we could not explain these findings. Maybe our lower prevalence of FTD follows the general prevalence of this type of dementia in Brazil. We do not have data about this prevalence by epidemiological surveys. Alcohol dementia was more frequent in epidemiological study in England ${ }^{24}$ than in our clinic perhaps due to evaluation by psychiatrists in our environment.

One point must be highlighted: patients spend a long time before to look for medical helping, as we could see observing age between onset of cognitive impairment and age of first evaluation, a mean of three years to go to medical assistance.

We can conclude that some differences exist between presenile and senile dementia in Brazil among studies. It is necessary more studies in different regions of our country about early onset dementia, and the ones with senile dementia clearly has showed $A D$ as principal cause of dementia ${ }^{9-13}$. Collaborative researches can clarify this picture.

\section{REFERENCES}

1. McGonigal G, Thomas B, Mcquade C, et al. Epidemiology of Alzheimer's presenile dementia in Scotland, 1974-88. Br Med J 1993;306:680-683.

2. Newens AJ, Forster DP, Kay DW, et al. Clinically diagnosed presenile dementia of the Alzheimer type in the Northern Health Region: ascertainment, prevalence, incidence and survival. Psychol Med 1993;23:631-644.

3. Treves T, Korczyn ADK, Zilber N, et al. Presenile dementia in Israel. Arch Neurol 1986;43:26-29.

4. Harvey RJ, Skelton-Robinson M, Rossor MN. The prevalence and causes of dementia in people under the age of 65 years. J Neurol Neurosurg Psychiatry 2003;74:1206-1209.
5. Hoffman A, Rocca WA, Brayne C, et al. The prevalence of dementia in Europe: a collaborative study of 1980-1990 findings. Int J Epidemiol 1991;20:736-748.

6. Jorm AF, Korten AE, Henderson AS. The prevalence of dementia: a quantitative integration of the literature. Acta Psychiatr Scand 1987;76:465-479.

7. Kokmen E, Beard CM, Offord KP, et al. Prevalence of medically diagnosed dementia in a defined United States population: Rochester, Minnesota, January 1 1975. Neurology 1989;39:773-776.

8. Varma AR, Adams W, Lloyd JJ, et al. Diagnostic patterns of regional atrophy on MRI and regional cerebral blood flow change on SPECT in young onset patients with Alzheimer's disease, frontotemporal dementia and vascular dementia. Acta Neurol Scand 2002;105:261-269.

9. Vale FAC, Miranda SJC. Clinical and demographic features of patients with dementia attended in a tertiary outpatient clinic. Arq Neuropsiquiatr 2002;60:548-552.

10. Silva DW, Damasceno BP. Demência na população de pacientes do Hospital das Clínicas da UNICAMP. Arq Neuropsiquiatr 2002;60:996-999.

11. Caixeta L. Epidemiologia das diferentes formas de demência em Goiás. Arq Neuropsiquiatr 2003;61(Suppl 2):S19.

12. Takada LT, Caramelli P, Radanovic M, et al. Prevalence of potentially reversible dementias in a dementia outpatient clinic of a tertiary university-affiliated hospital in Brazil. Arq Neuropsiquiatr 2003;61:925-929.

13. Canineu PR, Damasceno BP, Silva MC. Prevalência de demências na população de pacientes idosos (60 anos) internados no serviço de saúde Dr Cândido Ferreira da Prefeitura Municipal de Campinas. Arq Neuropsiquiatr 2003;61(Suppl 2):S21.

14. Engelhardt E, Laks J, Leibing A, et al. Demência pré-senil: aspectos preliminares. Arq Neuropsiquiatr 2001;59(suppl 3):S3-S4.

15. American Psychiatric Association. Diagnostic and statistical manual of mental disorders, 4.Ed. (DSM-IV). Washington DC: APA, 1994.

16. McKhann G, Drachman D, Folstein M, Katzman R, Price D, Stadlan EM. Clinical diagnosis of Alzheimer's disease: report of the NINCDS / ADRDA Work Group under the auspices of Department of Health and Human Services Task Force on Alzheimer's disease. Neurology 1984; 34:939-944.

17. Roman GC, Tatemichi TK, Erkinjuntti T, et al. Vascular dementia: diagnostic criteria for research studies. Report of the NINDS/ AIREN International Workshop. Neurology 1993;43:250-260.

18. McKeith IG, Galasko D, Kosaka K, et al. Consensus guidelines for the clinical and pathological diagnosis of dementia with Lewy bodies (DLB): report of the consortium on DLB international workshop. Neurology 1996;47:1113-1124.

19. McKeith IG, Perry EK, Perry RH. Report of the second dementia with Lewy body international workshop: diagnosis and treatment. Consortium on dementia with Lewy bodies. Neurology 1999;53:902-905.

20. The Lund and Manchester Groups. Clinical and neuropathological criteria for frontotemporal dementia. J Neurol Neurosurg Psychiatry. 1994;57:416-418.

21. Petersen, RC, Stevens, JC, Ganguli MC, et al. Early detection of dementia: mild cognitive impairment (an evidence-based review): report of the Quality Standards Subcommittee of the American Academy of Neurology. Neurology 2001;56:1133-1142.

22. Brucki SMD, Nitrini R, Caramelli P, Bertolucci PHF, Okamoto IH. Sugestões para o uso do Mini-Exame do Estado Mental no Brasil. Arq Neuropsiquiatr 2003;61:777-781.

23. Panegyres PK, Dvaies SR, Connor CF. Early-onset dementia. Med J Aust 2000:173:279-280.

24. Harvey RJ, Rossor MN, Skelton-Robinson M, Garralda E. Young onset dementia: epidemiology, clinical symptoms, family burden, support and outcome. Dementia Research Group. London.1998.

25. Elberling TV, Stokholm J, Hogh P, Waldemar, G. Diagnostic profile of young and middle-aged memory clinic patients. Neurology 2002;59:1259-1262.

26. Woodburn KJ, Johnstone EC. Early-onset dementia in Lothian, Scotland: an analysis of clinical features and patterns of decline. Health Bull (Edinb) 1999;57:384-392.

27. Delaney N, Rosenvinge H. Presenile dementia: suffers, careers and services. Int J Geriatr Psychiatry 1995;10:597-601.

28. Ikeda M, Hokoishi $\mathrm{K}$, Maki N, et al. Increased prevalence of vascular dementia in Japan: a community-based epidemiological study. Neurology 2001;57:839-844. 